\title{
PENGARUH SUBSTITUSI UBI JALAR KUNING, ISOLAT PROTEIN KEDELAI, DAN TEPUNG DAUN KELOR TERHADAP KANDUNGAN GIZI SERTA DAYA TERIMA MI INSTAN
}

\author{
Effect of Yellow Sweet Potato, Isolated Soy Protein and Moringa Leaves Powder Substitution on \\ Nutritional Value and Acceptability of Instant Noodle
}

Ranty Restiartanti Agus ${ }^{*}$, Rita Ismawati ${ }^{2}$

${ }^{1}$ Program Studi S1 Ilmu Gizi, Fakultas Kesehatan Masyarakat, Universitas Airlangga, Surabaya ${ }^{2}$ Prodi Gizi, Jurusan PKK, Fakultas Teknik, Universitas Negeri Surabaya

E-mail: rantyartantia@gmail.com

\begin{abstract}
ABSTRAK
Mi instan merupakan alternatif sumber energi berbasis tepung terigu, yang tingkat konsumsinya di Indonesia cukup tinggi. Inovasi mi instan yang disubstitusi dengan pangan lokal merupakan solusi untuk mengurangi ketergantungan terhadap tepung terigu. Ubi jalar kuning memiliki nilai energi yang mendekati tepung terigu, begitu pula isolat protein kedelai yang tinggi kandungan protein dan daun kelor yang tinggi kandungan kalsium. Tujuan penelitian ini adalah mengetahui efek substitusi ubi jalar kuning, isolat protein kedelai dan daun kelor terhadap daya terima serta nilai gizi (energi, protein dan kalsium) pada mi instan. Jenis penelitian adalah eksperimental dengan desain Rancangan Acak Lengkap (RAL). Terdapat 1 formula kontrol (F0) dan dua formula substitusi ubi jalar kuning, isolat protein kedelai, dan tepung daun kelor (F1 dan F2) dengan 8 kali pengulangan. Panelis yang digunakan adalah panelis tidak terlatih sebanyak 33 ibu hamil. Perbedaan daya terima dianalisis menggunakan uji Kruskal Wallis dan Mann Whitney pada $\alpha$ $\leq 0,05$. Hasil penilaian daya terima menunjukkan formula yang paling disukai panelis adalah F2 (substitusi $6,8 \%$ ubi jalar kuning, 5,4\% isolat protein kedelai, dan 1,4\% tepung daun kelor) terdapat perbedaan yang signifikan antara F0 dengan F2 ( $p=0,004)$ dan F1 dengan F2 ( $p=0,013)$ pada karakteristik aroma. Peningkatan protein dan kalsium per 100 $\mathrm{g}$ mi instan tertinggi adalah F2 yaitu $14 \mathrm{~g}$ dan $44,5 \mathrm{mg}$. Formula terbaik ditinjau dari daya terima serta nilai gizi (energi, protein dan kalsium) terbaik adalah F2 (substitusi $25 \mathrm{~g}$ ubi jalar kuning, $20 \mathrm{~g}$ isolat protein kedelai, dan $5 \mathrm{~g}$ tepung daun kelor), sehingga dapat digunakan sebagai salah satu alternatif pemberian makanan tambahan bagi ibu hamil.
\end{abstract}

Kata kunci: daun kelor, isolat protein kedelai, mi instan, ubi jalar kuning

\begin{abstract}
Instant noodle is an alternative source of energy based on wheat flour. The consumption of instant noodle in Indonesia is quite high. Instant noodle innovation with local food substitution is a solution to reduce dependence on wheat flour. Yellow sweet potato has an energy value similar to wheat flour, as well as isolated soy protein high in protein and moringa leaves powder high in calcium. The purpose of this research was to analyse the effect of yellow sweet potato, isolated soy protein, and moringa leaves powder substitution on acceptability and nutritional value (energy, protein, and calcium) of instant noodle. This was experimental research with completely randomized design. There were three formulas, one as a control formula (F0) and two substitution formulas with yellow sweet potato, isolated soy protein, and moringa leaves (F1 and F2) with 8 repetitions. There were 33 pregnant women as untrained panelist. The difference test was analyzed by Kruskall Wallis and Mann Whitney $(\alpha \leq 0.05)$. The result of panelist acceptability showed that the best formula is F2 (substitution of $6.8 \%$ yellow sweet potato, 5.4\% isolated soy protein, and $1.4 \%$ moringa leaves powder). There was a significant difference between F0 with F2 ( $p=0.004)$ and F1 with F2 ( $p=0.013)$ on aroma characteristics. The highest protein and calcium content per $100 \mathrm{~g}$ of instant noodle was F2, with $14 \mathrm{~g}$ and $44.5 \mathrm{mg}$. The best formula which determinated by the acceptability and nutritional value (energy, protein and calcium) was F2 (substitution of $25 \mathrm{~g}$ yellow sweet potato, $20 \mathrm{~g}$ isolated soy protein, and $5 \mathrm{~g}$ moringa leaves powder), so it can be used as an alternative food for pregnant women.
\end{abstract}

Keywords: instant noodles, isolated soy protein, moringa leaves, yellow sweet potato

Ranty R.A., dan Rita I. MGI (2018) 108-116

DOI: $10.20473 /$ mgi.v13i2.108-116 


\section{PENDAHULUAN}

Daya terima masyarakat Indonesia terhadap mi instan cukup tinggi, ditandai dengan data Riskesdas yang menyatakan bahwa satu diantara sepuluh masyarakat Indonesia mengonsumsi mi instan sebanyak $\geq 1$ kali per hari (Kemenkes, 2013a). Sama seperti namanya, mi instan merupakan makanan yang sifatnya praktis, mudah dibuat, dan dapat ditemukan dimana saja (Rochmawati dan Marlenywati, 2015), sehingga banyak yang menyukai mi instan bahkan dijadikan makanan pendamping nasi (lauk).

Minat masyarakat Indonesia terhadap pangan berbasis terigu ditandai dengan meningkatnya jumlah impor gandum ke Indonesia yang mencapai 7 juta ton pada tahun 2015, sehingga Indonesia menjadi pengimpor gandum terbesar nomor dua di dunia (Badan Pusat Statistik, 2016). Solusi yang dapat dilakukan untuk mengurangi ketergantungan masyarakat akan terigu adalah pemanfaatan pangan lokal, seperti umbi-umbian, kacang-kacangan dan sayuran.

Salah satu pangan lokal dari umbi-umbian yang berpotensi untuk dimanfaatkan dengan baik adalah ubi jalar kuning. Ubi jalar kuning mengandung beragam zat gizi mikro, antara lain beta karoten sebagai pro vitamin A sebesar 3.000-20.000 $\mu \mathrm{g} / 100 \mathrm{~g}$ yang setara dengan wortel, kandungan vitamin $\mathrm{C}$ sebesar $25 \mathrm{mg} / 100 \mathrm{~g}$, serat pangan sebesar $3,9 \mathrm{~g} / 100 \mathrm{~g}$ yang lebih tinggi dari pada roti tawar $(2,7 \mathrm{~g} / 100 \mathrm{~g})$, indeks glikemik yang rendah (54-68), serta mengandung setidaknya 114,5 kkal energi per 100 gram yang setara dengan nasi (Ginting et al., 2014).

Isolat protein kedelai merupakan konsentrat protein kedelai yang memiliki sifat fungsional yang baik karena tinggi kandungan protein, yaitu minimal 90\% protein (Slavin, 1991). Daya cerna protein pada isolat protein kedelai sangat baik, yaitu sebesar 86\% (Mariotti et al., 1999).

Berdasarkan penelitian Ponomban et al. (2013) daun kelor merupakan sayuran lokal yang memiliki kandungan gizi baik makro maupun mikro yang beragam, antara lain kalsium, kalium, zat besi, vitamin $\mathrm{C}$, beta karoten, dan protein. Kandungan kalsium pada daun kelor empat kali lebih banyak dari pada susu atau yogurt.
Banyaknya manfaat dari pangan lokal yaitu ubi jalar kuning, isolat protein kedelai, dan tepung daun kelor, membuat pangan lokal tersebut dapat disubsitusikan pada produk pangan yang ditujukan pada ibu hamil. Hal ini didasarkan karena sebagian besar ibu hamil tidak mampu menentukan frekuensi dan porsi makanan yang tepat. Ibu hamil hanya memahami bahwa porsinya harus dua kali lebih banyak dari pada kondisi normal, sehingga memicu adanya ketidakseimbangan asupan gizi pada ibu hamil akibat konsumsi yang tidak terpenuhi kebutuhan gizinya secara keseluruhan (Hasanah et al., 2012).

Mengingat mi instan merupakan produk pangan yang dihindari oleh kebanyakan ibu hamil akibat pengaruh budaya masyarakat setempat yang menyatakan bahwa makanan tersebut tidak sehat (Oktriyani et al., 2014). Serta adanya penelitian Cindy et al. (2016) yang menyatakan bahwa mi instan mengandung zat gizi cukup terbatas yaitu didominasi oleh karbohidrat, sedangkan protein, lemak, dan vitamin maupun mineral relatif rendah. Maka, apabila pangan lokal berupa ubi jalar kuning, isolat protein kedelai, dan tepung daun kelor dipadukan dengan mi instan dapat menjadi suatu pangan yang potensial bagi ibu hamil terutama yang mengalami KEK, yaitu berupa pemberian makanan tambahan (PMT).

Di Indonesia, kejadian ibu hamil kekurangan energi kronis (KEK) hampir merata di seluruh wilayah (Kemenkes, 2013b). KEK merupakan suatu keadaan kekurangan energi terutama dari protein, yang ditandai dengan ukuran lingkar lengan atas (LILA) sebesar kurang dari $23 \mathrm{~cm}$ (Syukur, 2016). Selain itu terdapat permasalahan gizi lain yaitu preeklampsia yang merupakan penyebab terbesar nomor dua kematian ibu hamil di dunia (Say et al., 2014). Berdasarkan penelitian yang dilakukan Camargo et al. (2013), kalsium tidak hanya penting bagi kesehatan tulang ibu dan janin, namun asupan kalsium yang adekuat pada masa kehamilan mampu menurunkan risiko terjadinya preeklamsia, hipertensi, maupun kelahiran yang prematur.

Adanya inovasi PMT menggunakan bahan pangan lokal seperti ubi jalar kuning, isolat protein kedelai, dan tepung daun kelor pada mi instan 
dapat menjadi salah satu cara untuk menekan penggunaan terigu sehingga memberikan solusi dalam mengatasi ketergantungan masyarakat terhadap terigu serta upaya untuk meningkatkan nilai gizi dari mi instan sehingga layak untuk dikonsumsi ibu hamil dengan permasalahan gizi seperti KEK dan preeklamsia. Penelitian ini bertujuan untuk mengetahui efek substitusi ubi jalar kuning, isolat protein kedelai, dan tepung daun kelor pada mi instan dengan menentukan formula terbaik dari dua formula mi instan, yang didasarkan dari penilaian daya terima dan nilai gizi (energi, protein dan kalsium).

\section{METODE}

Penelitian ini merupakan penelitian eksperimental dengan desain Rancangan Acak Lengkap (RAL), serta terdapat 2 (dua) perlakuan dan 8 kali pengulangan. Penelitian dilaksanakan pada bulan Juni-Juli 2017. Pembuatan mi instan dilakukan di Laboratorium Pengolahan, Fakultas Kesehatan Masyarakat Universitas Airlangga. Uji daya terima di Puskesmas Keputih Surabaya, serta uji nilai gizi (energi, protein dan kalsium) di Laboratorium Gizi Fakultas Kesehatan Masyarakat Universitas Airlangga.

Pengujian daya terima dilakukan untuk menilai karakteristik warna, aroma, tekstur, dan rasa mi instan substitusi ubi jalar kuning, isolat protein kedelai, dan tepung daun kelor. Sampel penelitian adalah mi instan substitusi ubi jalar kuning, isolat protein kedelai, dan tepung daun kelor dengan formulasi yang telah ditentukan. Sampel yang disajikan pada panelis adalah $10 \mathrm{~g}$ untuk masing-masing formula mi instan. Panelis pada penelitian ini adalah panelis tidak terlatih yaitu ibu hamil di Puskesmas Keputih Surabaya sebanyak 33 orang. Ibu hamil dipilih sebagai panelis karena inovasi mi instan ini ditujukan sebagai alternatif pemberian makanan tambahan (PMT) bagi ibu hamil. Air mineral diberikan kepada panelis dengan tujuan untuk menetralkan indera pengecap. Skala penilaian uji daya terima menggunakan 5 kategori (1: sangat tidak suka, 2: tidak suka, 3: agak suka, 4: suka, dan 5: sangat suka). Uji Kruskal Wallis pada $\alpha \leq 0,05$ digunakan untuk mengetahui perbedaan pengaruh substitusi ubi jalar kuning, isolat protein kedelai, dan tepung daun kelor terhadap daya terima mi instan dan Mann Whitney pada $\alpha \leq 0,05$ untuk mengetahui perbedaan tiap formula yang paling signifikan.

Perhitungan kandungan energi, protein dan kalsium berdasarkan perhitungan (Daftar Komposisi Bahan Makanan) Depkes RI (1995), sedangkan pengujian nilai gizi (energi, protein dan kalsium) dilakukan dengan analisis laboratorium. Sampel yang digunakan untuk uji nilai gizi (energi, protein dan kalsium) adalah $100 \mathrm{~g}$ untuk mi instan formula terbaik dari penilaian daya terima. Pengambilan sampel dilakukan secara acak dari hasil pengulangan pada setiap perlakuan.

Bahan yang digunakan dalam pembuatan mi instan adalah tepung terigu protein tinggi, ubi jalar kuning, isolat protein kedelai, tepung daun kelor, telur, garam, dan air. Penggunaan substitusi ubi jalar kuning, isolat protein kedelai, dan tepung daun kelor berfungsi sebagai alternatif sumber energi, protein dan kalsium yang berpengaruh pada peningkatan kadar energi, protein dan kalsium pada mi instan. Formulasi mi instan substitusi ubi jalar kuning, isolat protein kedelai, dan tepung daun kelor yang digunakan dalam penelitian disajikan pada Tabel 1.

Tahapan dalam pembuatan mi instan, diawali dengan persiapan alat dan bahan yang digunakan dalam pembuatan mi instan, pencampuran bahan diawali dari bahan kering kemudian bahan basah, lalu seluruh bahan diaduk hingga kalis. Adonan digiling menggunakan alat penggiling mi hingga berbentuk pipih dan bertekstur halus. Adonan kemudian dicetak berbentuk silinder panjang seperti mi pada umumnya. Mi kemudian dikukus dengan suhu $100^{\circ} \mathrm{C}$ selama 10 menit,

Tabel 1. Formula Mi Instan

\begin{tabular}{lccc}
\hline \multirow{2}{*}{ Bahan Inti } & \multicolumn{3}{c}{ Formula Mi Instan (g) } \\
\cline { 2 - 4 } & F0 & F1 & F2 \\
\hline Tepung terigu & 250 & 225 & 200 \\
Ubi jalar kuning & 0 & 12,5 & 25 \\
Isolat protein kedelai & 0 & 10 & 20 \\
Tepung daun kelor & 0 & 2,5 & 5 \\
Telur & 60 & 60 & 60 \\
Air & 50 & 50 & 50 \\
Garam & 10 & 10 & 10 \\
Total & 370 & 370 & 370 \\
\hline
\end{tabular}


Tabel 2. Distribusi Tingkat Kesukaan Panelis terhadap Warna Mi Instan

\begin{tabular}{|c|c|c|c|c|c|c|c|c|c|c|c|c|c|}
\hline \multirow{3}{*}{ Formula } & \multicolumn{10}{|c|}{ Penilaian Warna Mi Instan } & \multirow{2}{*}{\multicolumn{2}{|c|}{ Total }} & \multirow{3}{*}{ Mean } \\
\hline & \multicolumn{2}{|c|}{1} & \multicolumn{2}{|c|}{2} & \multicolumn{2}{|c|}{3} & \multicolumn{2}{|c|}{4} & \multicolumn{2}{|c|}{5} & & & \\
\hline & $\mathbf{n}$ & $(\%)$ & $\mathbf{n}$ & $(\%)$ & $\mathbf{n}$ & $(\%)$ & $\mathbf{n}$ & $(\%)$ & $\mathbf{n}$ & $(\%)$ & $\mathbf{N}$ & $(\%)$ & \\
\hline F0 & 1 & 3,0 & 6 & 18,2 & 3 & 9,1 & 17 & 51,5 & 6 & 18,2 & 33 & 100 & 3,6 \\
\hline F1 & 0 & 0,0 & 4 & 12,1 & 4 & 12,1 & 14 & 42,4 & 11 & 33,3 & 33 & 100 & 4,0 \\
\hline $\mathrm{F} 2$ & 0 & 0,0 & 3 & 9,1 & 9 & 27,3 & 15 & 45,5 & 6 & 18,2 & 33 & 100 & 3,7 \\
\hline
\end{tabular}

lalu diletakkan daun jeruk purut diatasnya dengan proporsi berbeda (F0: tidak diberikan, F1: 2 lembar dan F2: 3 lembar), kemudian digoreng dengan metode deep fat frying pada suhu $140-150^{\circ} \mathrm{C}$ selama 1-1,5 menit (Liandani dan Zubaidah, 2015). Penggunaan daun jeruk purut pada proses pengukusan difungsikan untuk meminimalisir aroma langu dan rasa pahit yang dihasilkan oleh tepung daun kelor (Khasanah et al., 2015).

Terdapat dua variabel pada penelitian ini, yaitu variabel bebas dan terikat. Variable bebas meliputi komposisi substitusi ubi jalar kuning, isolat protein kedelai, dan tepung daun kelor, sedangkan variabel terikat meliputi daya terima dan nilai gizi (energi, protein dan kalsium).

Penelitian ini melibatkan subyek manusia (ibu hamil) sebagai panelis untuk menilai daya terima produk. Maka, penelitian ini telah mendapatkan persetujuan dari komisi etik penelitian kesehatan Fakultas Kesehatan Masyarakat Universitas Airlangga dengan nomor 288-KEPK.

\section{HASIL DAN PEMBAHASAN}

Hasil penilaian tingkat kesukaan warna mi instan oleh panelis tidak terlatih (ibu hamil) disajikan pada tabel 2 yang menunjukkan tingkat kesukaan warna tertinggi adalah F1 dengan mean rank 4. Warna mi instan pada F1 adalah kuning kehijauan.

Hal ini disebabkan karena adanya substitusi ubi jalar kuning sebanyak 12,5 g dan isolat protein kedelai sebanyak $10 \mathrm{~g}$ yang berwarna kekuningan serta daun kelor sebanyak 2,5 g yang berwarna kehijauan. Panelis lebih menyukai mi dengan warna hijau yang tidak terlalu pekat. Tepung daun kelor yang disubstitusikan tidak terlalu banyak dan adanya substitusi ubi jalar kuning yang berwarna kuning menimbulkan warna hijau kekuningan yang disukai panelis. Substitusi tepung daun kelor pada mi akan memengaruhi warna mi, yaitu semakin tinggi konsentrasi substitusi tepung daun kelor maka warna hijau pada mi akan semakin pekat (Zakaria et al., 2016). Selain itu, adanya proses pemanasan akan menyebakan terjadinya reaksi maillard yang terjadi akibat adanya interaksi antara pati dan protein atau gugus asam amino sehingga menurunkan kecerahan warna pada mi yang dihasilkan (Trisnawati dan Nisa, 2015).

Hasil analisis statistik menggunakan kruskal wallis menunjukkan perlakuan yang diberikan tidak berpengaruh signifikan terhadap karakteristik warna mi instan substitusi ubi jalar kuning, isolat protein kedelai, dan tepung daun kelor $(\mathrm{p}=0,327)$. Warna yang tidak berpengaruh signifikan menunjukkan panelis rata-rata menyukai semua formula mi instan.

Tabel 3 menunjukkan tingkat kesukaan aroma tertinggi adalah F2 dengan mean rank 4,1. Aroma pada mi instan F2 adalah kombinasi aroma khas kelor dengan aroma daun jeruk purut. Hal ini disebabkan karena adanya substitusi tepung daun kelor sebanyak 5 g serta penggunaan daun jeruk purut yang lebih banyak dari pada formula lain yaitu sebanyak 3 lembar pada saat proses pengukusan.

Tabel 3. Distribusi Tingkat Kesukaan Panelis terhadap Aroma Mi Instan

\begin{tabular}{|c|c|c|c|c|c|c|c|c|c|c|c|c|c|}
\hline \multirow{3}{*}{ Formula } & \multicolumn{10}{|c|}{ Penilaian Aroma Mi Instan } & \multirow{2}{*}{\multicolumn{2}{|c|}{ Total }} & \multirow{3}{*}{ Mean } \\
\hline & \multicolumn{2}{|c|}{1} & \multicolumn{2}{|c|}{2} & \multicolumn{2}{|c|}{3} & \multicolumn{2}{|c|}{4} & \multicolumn{2}{|c|}{5} & & & \\
\hline & $\mathbf{n}$ & $(\%)$ & $\mathbf{n}$ & $(\%)$ & $\mathbf{n}$ & $(\%)$ & $\mathbf{n}$ & $(\%)$ & $\mathbf{n}$ & $(\%)$ & $\mathbf{N}$ & $(\%)$ & \\
\hline F0 & 0 & 0 & 9 & 27,3 & 5 & 15,2 & 16 & 48,5 & 3 & 9,1 & 33 & 100 & 3,4 \\
\hline F1 & 0 & 0 & 6 & 18,2 & 9 & 27,3 & 13 & 39,4 & 5 & 15,1 & 33 & 100 & 3,5 \\
\hline $\mathrm{F} 2$ & 0 & 0 & 2 & 6,1 & 4 & 12,1 & 16 & 48,5 & 11 & 33,3 & 33 & 100 & 4,1 \\
\hline
\end{tabular}


Tabel 4. Distribusi Tingkat Kesukaan Panelis terhadap Tekstur Mi Instan

\begin{tabular}{|c|c|c|c|c|c|c|c|c|c|c|c|c|c|}
\hline \multirow{3}{*}{ Formula } & \multicolumn{10}{|c|}{ Penilaian Tekstur Mi Instan } & \multirow{2}{*}{\multicolumn{2}{|c|}{ Total }} & \multirow{3}{*}{ Mean } \\
\hline & \multicolumn{2}{|c|}{1} & \multicolumn{2}{|c|}{2} & \multicolumn{2}{|c|}{3} & \multicolumn{2}{|c|}{4} & \multicolumn{2}{|c|}{5} & & & \\
\hline & $\mathbf{n}$ & $(\%)$ & $\mathbf{n}$ & $(\%)$ & $\mathbf{n}$ & $(\%)$ & $\mathbf{n}$ & $(\%)$ & $\mathbf{n}$ & $(\%)$ & $\mathbf{N}$ & $(\%)$ & \\
\hline F0 & 1 & 3 & 2 & 6,1 & 5 & 15,2 & 19 & 57,6 & 6 & 18,2 & 33 & 100 & 3,8 \\
\hline F1 & 0 & 0 & 1 & 3 & 8 & 24,2 & 19 & 57,6 & 5 & 15,2 & 33 & 100 & 3,9 \\
\hline $\mathrm{F} 2$ & 0 & 0 & 0 & 0 & 6 & 18,2 & 19 & 57,6 & 8 & 24,2 & 33 & 100 & 4,1 \\
\hline
\end{tabular}

Aroma langu pada daun kelor berdasarkan penelitian Zakaria et al. (2016) menyebabkan daya terima panelis terhadap aroma mi menjadi rendah. Hal ini selaras dengan penelitian Trisnawati dan Nisa (2015) yang menyatakan bahwa semakin banyak konsentrat daun kelor yang ditambahkan dapat mengakibatkan aroma langu semakin menyengat. Untuk meminimalisir aroma langu dari tepung daun kelor, peneliti memberikan perlakuan tambahan yaitu dengan menambahkan daun jeruk purut dalam proses pengukusan mi instan sehingga aroma langu dari tepung daun kelor dapat tersamarkan dengan aroma daun jeruk purut. Daun jeruk purut mengandung minyak atsiri dengan komponen utamanya adalah sitronellal. Minyak atsiri merupakan suatu zat yang mudah menguap dan dapat dimanfaatkan sebagai pemberi aroma dan rasa pada produk-produk olahan pangan (Khasanah et al., 2015).

Hasil analisis statistik menggunakan kruskal wallis menunjukkan perlakuan yang diberikan berpengaruh signifikan terhadap karakteristik aroma mi instan substitusi ubi jalar kuning, isolat protein kedelai, dan tepung daun kelor $(\mathrm{p}=0,008)$. Perbedaan jumlah proporsi ubi jalar kuning, isolat protein kedelai, dan tepung daun kelor berpengaruh nyata pada mi instan F0 dengan F2 dan F1 dengan $\mathrm{F} 2$, namun tidak dengan mi instan F0 dan F1. Adanya substitusi tepung daun kelor dan penambahan daun jeruk purut yang lebih banyak pada F2 membuat panelis lebih menyukai mi instan formula ini karena memiliki aroma yang kuat.
Rata-rata panelis yang merupakan ibu hamil justru kurang menyukai aroma terigu yang kuat pada F0 karena dapat menyebabkan mual. Hal ini didasarkan pada perubahan fisik pada ibu selama kehamilan yaitu adanya kepekaan terhadap indera penciuman sehingga lebih sensitif terhadap aroma tertentu (Cameron, 2014).

Tabel 4 menunjukkan tingkat kesukaan tekstur tertinggi adalah F2 dengan mean rank 4,1. Tekstur pada mi instan F2 adalah kenyal, namun apabila dibandingkan dengan F1 dan F0, terjadi penurunan elastisitas, dengan ciri-ciri lebih mudah patah. Elastisitas mi dipengaruhi oleh senyawa gluten, sedangkan pada konsentrat protein yang ditambahkan pada mi tidak mengandung senyawa gluten yang mampu meningkatkan elastisitas mi (Trisnawati dan Nisa, 2015).

Hasil analisis statistik menggunakan kruskal wallis menunjukkan perlakuan yang diberikan tidak berpengaruh signifikan terhadap karakteristik tekstur mi instan substitusi ubi jalar kuning, isolat protein kedelai, dan tepung daun kelor $(\mathrm{p}=0,482)$. Hal ini menunjukkan bahwa tidak ada perbedaan karakteristik tekstur antara mi instan formula kontrol (F0) dengan formula substitusi (F1 dan F2). Hasil penilaian tekstur yang tidak berpengaruh signifikan menunjukkan tingkat kesukaan panelis yang memberikan penilaian rata-rata menyukai semua formula mi instan.

Tabel 5 menunjukkan tingkat kesukaan rasa tertinggi adalah F2 dengan mean rank 3,8. Rasa pada mi instan F2 adalah gurih khas mi namun

Tabel 5. Distribusi Tingkat Kesukaan Panelis terhadap Rasa Mi Instan

\begin{tabular}{|c|c|c|c|c|c|c|c|c|c|c|c|c|c|}
\hline \multirow{3}{*}{ Formula } & \multicolumn{10}{|c|}{ Penilaian Rasa Mi Instan } & \multirow{2}{*}{\multicolumn{2}{|c|}{ Total }} & \multirow{3}{*}{ Mean } \\
\hline & \multicolumn{2}{|c|}{1} & \multicolumn{2}{|c|}{2} & \multicolumn{2}{|c|}{3} & \multicolumn{2}{|c|}{4} & \multicolumn{2}{|c|}{5} & & & \\
\hline & $\mathbf{n}$ & $(\%)$ & $\mathbf{n}$ & $(\%)$ & $\mathbf{n}$ & $(\%)$ & $\mathbf{n}$ & $(\%)$ & $\mathbf{n}$ & $(\%)$ & $\mathbf{N}$ & $(\%)$ & \\
\hline F0 & 4 & 12,1 & 4 & 12,1 & 8 & 24,2 & 14 & 42,4 & 3 & 9,1 & 33 & 100 & 3,2 \\
\hline F1 & 3 & 9,1 & 3 & 9,1 & 6 & 18,2 & 14 & 42,4 & 7 & 21,2 & 33 & 100 & 3,6 \\
\hline $\mathrm{F} 2$ & 0 & 0 & 3 & 9,1 & 10 & 30,3 & 10 & 30,3 & 10 & 30,3 & 33 & 100 & 3,8 \\
\hline
\end{tabular}


terdapat sedikit rasa pahit setelah dikonsumsi. Hal ini disebabkan karena adanya substitusi tepung daun kelor sebanyak $5 \mathrm{~g}$. Menurut Luthfiyah (2012), rasa pahit dari tepung kelor disebabkan adanya senyawa fenolik dan alkaloid. Rasa pahit pada daun kelor berdasarkan penelitian Zakaria et al. (2016) menyebabkan daya terima panelis terhadap rasa mi menjadi rendah. Hal ini selaras dengan penelitian Trisnawati et al. (2015) yang menyatakan bahwa semakin banyak konsentrat daun kelor yang ditambahkan dapat mengakibatkan rasa pahit semakin kuat.

Hasil analisis statistik menggunakan kruskal wallis menunjukkan perlakuan yang diberikan tidak berpengaruh signifikan terhadap karakteristik rasa mi instan substitusi ubi jalar kuning, isolat protein kedelai, dan tepung daun kelor $(\mathrm{p}=0,193)$. Adanya penambahan daun jeruk purut pada proses pengukusan dengan jumlah yang lebih banyak dari F1 diduga mampu memperbaiki cita rasa mi instan.

Menurut Khasanah et al., (2015), minyak atsiri pada daun jeruk purut mampu memberi aroma dan rasa pada produk-produk olahan pangan. Sehingga perpaduan antara rasa tepung daun kelor dan daun jeruk purut justru mampu menciptakan rasa yang cenderung disukai oleh ibu hamil.

Penilaian daya terima keseluruhan terhadap karakteristik warna, aroma, tekstur, dan rasa disajikan pada Gambar 1. Mi instan F2 (25 g ubi jalar kuning, $20 \mathrm{~g}$ isolat protein kedelai, dan $5 \mathrm{~g}$ tepung daun kelor) memiliki nilai tertinggi pada penilaian aroma, tekstur dan rasa, sedangkan mi instan F1 (12,5 g ubi jalar kuning, $10 \mathrm{~g}$ isolat protein kedelai, dan 2,5 $\mathrm{g}$ tepung daun kelor) memiliki nilai tertinggi pada penilaian warna.

Tingginya penilaian panelis terhadap mi instan formula substitusi F2 dibandingkan dengan mi instan formula kontrol (F0) menunjukkan bahwa mi instan formula substitusi F2 dapat menggantikan mi instan formula kontrol berdasarkan penilaian warna, aroma, tekstur dan rasa mi instan. Penilaian terbaik adalah F2 yang dijadikan formula terbaik berdasarkan daya terima yang dipilih ibu hamil dan sesuai untuk PMT ibu hamil.

Masa kehamilan membutuhkan zat gizi yang lebih banyak dan beragam dari pada kondisi normal akibat adanya perubahan fisiologis yang terjadi,

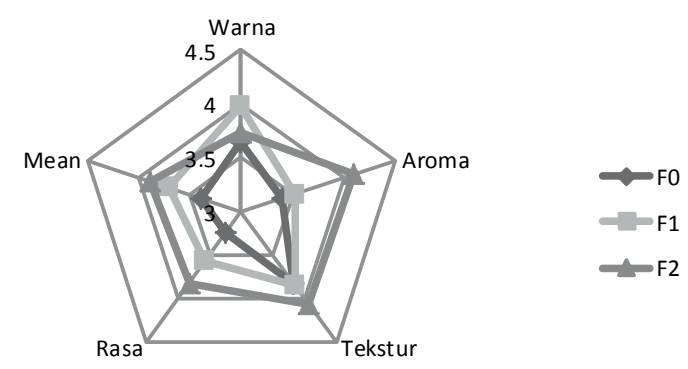

Gambar 1. Diagram Penilaian Keseluruhan Daya Terima Mi Instan

selain itu pemilihan makanan yang dikonsumsi juga harus diperhatikan karena digunakan untuk memenuhi kebutuhan ibu dan janin. Tidak tercukupinya kebutuhan gizi pada masa kehamilan dapat memengaruhi kondisi ibu dan janin dengan adanya permasalahan gizi kehamilan, seperti KEK, anemia, bahkan berat bayi lahir rendah (BBLR) (Karima dan Achadi, 2012).

Berdasarkan AKG, ibu hamil usia 19-29 tahun membutuhkan energi kurang lebih sebesar $2500 \mathrm{kkal} /$ hari, protein sebesar $76 \mathrm{~g} /$ hari, kalsium sebesar $1300 \mathrm{mg} / \mathrm{hari}$, dan zat besi sebesar 35 $\mathrm{mg} /$ hari (Kemenkes, 2013a). Total energi yang dibutuhkan ibu hamil bergantung pada aktivitas fisik yang dilakukan dan peningkatan Basal Metabolic Rate (BMR).

Tabel 6 menunjukkan kandungan zat gizi per 100 gram mi instan F2 berdasarkan hasil perhitungan DKBM dan uji laboratorium. Pada hasil perhitungan DKBM, mi instan memiliki kandungan energi yang lebih rendah dari pada hasil uji laboratorium, sedangkan kandungan energi, protein dan kalsiumnya lebih tinggi dari pada hasil uji laboratorium. Perhitungan tersebut didasarkan pada DKBM bahan mentah sebelum

Tabel 6. Nilai Gizi Mi Instan Formula Substitusi F2 per 100 Gram

\begin{tabular}{ccccc}
\hline Formula & $\begin{array}{c}\text { Mi } \\
\text { Instan } \\
\text { F2 }^{1}\end{array}$ & $\begin{array}{c}\text { Mi } \\
\text { Instan } \\
\text { F2 }^{2}\end{array}$ & $\begin{array}{c}\text { Mi Instan } \\
\text { Komersil }^{3}\end{array}$ & $\begin{array}{c}\text { SNI Mi } \\
\text { Instan }^{4}\end{array}$ \\
\hline Energi (kkal) & 251 & 273,5 & 360 & - \\
Protein (g) & 14 & 8,3 & 4,7 & Min. 8 \\
Kalsium (g) & 44,5 & 30,8 & 6 & - \\
\hline
\end{tabular}

${ }^{1}$ DKBM (Depkes, 1995)

${ }^{2}$ Hasil uji laboratorium

${ }^{3}$ Astawan, (2008)

${ }^{4}$ SNI No. 01-3551-2000 (BSN, 2000) 
dilakukan pengolahan. Peningkatan kandungan energi mi instan disebabkan karena adanya proses pengolahan berupa penggorengan yang menyebabkan kandungan lemak pada makanan mengalami kenaikan yang disebabkan oleh terserapnya minyak goreng pada makanan tersebut sehingga mengakibatkan kadar lemak bertambah (Sundari et al., 2015). Tingginya kandungan energi pada mi instan dianggap baik karena sesuai dengan sasaran yaitu ibu hamil KEK yang memang membutuhkan asupan kalori lebih.

Nilai protein yang cenderung menurun pada uji laboratorium disebabkan adanya proses pemasakan berupa penggorengan dengan metode deep fat frying pada suhu $140-150^{\circ} \mathrm{C}$. Proses penggorengan menggunakan suhu tinggi mengakibatkan rusaknya kandungan protein, sehingga kandungan protein pada makanan menurun (Sundari et al., 2015).

Hal ini selaras dengan penelitian Nurhidajah et al. (2009) yang menyatakan bahwa tempe yang diolah dengan cara digoreng memiliki kandungan protein lebih rendah jika dibandingkan dengan tempe yang diolah dengan cara dikukus. Karena pada proses penggorengan, sebagian minyak goreng akan menempati rongga-rongga pada bahan dan menggantikan air yang menguap, sehingga konsentrasi protein persatuan berat bahan menjadi lebih kecil. Walaupun terdapat penurunan, kandungan protein pada mi instan F2 tetap sesuai dengan SNI No. 01-3551-2000, yaitu lebih dari $8 \mathrm{~g}$ per $100 \mathrm{~g}$ mi instan dan jauh lebih tinggi daripada kandungan protein mi instan komersial.

Menurunnya kandungan kalsium pada mi instan disebabkan oleh adanya proses pemasakan dengan suhu tinggi. Pemasakan dengan suhu tinggi mampu merusak kandungan zat gizi terutama kalsium, yodium, seng, selenium, dan zat besi di dalam makanan secara signifikan sebanyak 5-40\% (Sundari, 2015). Sama seperti protein, walaupun terdapat penurunan kandungan kalsium, kandungan kalsium pada mi instan F2 tetap jauh lebih tinggi daripada kandungan kalsium mi instan komersial.

Kontribusi mi instan formula substitusi F2 terhadap AKG dan standar PMT Ibu Hamil disajikan pada Tabel 7. Mi instan substitusi ubi jalar kuning, isolat protein kedelai, dan tepung daun kelor menyumbang sebanyak 357,6 kkal energi per sajian, sehingga mampu berkontribusi sebanyak $14 \%$ terhadap AKG ibu hamil dan sebanyak $82,2 \%$ dalam memenuhi standar PMT ibu hamil.

Hal ini berarti bahwa total energi yang dikandung pada mi instan substitusi ubi jalar kuning, isolat protein kedelai, dan tepung daun kelor pada formula terbaik mampu memenuhi $10-15 \%$ kebutuhan PMT dalam AKG. Tingginya kandungan energi pada mi instan dianggap baik karena sesuai dengan sasaran yaitu ibu hamil KEK yang membutuhkan asupan kalori lebih.

Mi instan substitusi ubi jalar kuning, isolat protein kedelai, dan tepung daun kelor formula terbaik menyumbang sebanyak 20 gram protein per sajian, sehingga mampu berkontribusi sebanyak 26,3\% terhadap AKG ibu hamil dan sebanyak $200 \%$ dalam memenuhi PMT ibu hamil. Hal ini berarti bahwa protein yang dikandung pada mi instan substitusi ubi jalar kuning, isolat protein kedelai, dan tepung daun kelor formula terbaik mampu memenuhi lebih dari 15\% kebutuhan PMT dalam AKG. Tingginya protein pada mi instan berasal dari isolat protein kedelai yang mengandung protein minimal 90\% (Slavin, 1991) dan tepung daun kelor yang mengandung 25,34-26,98 g protein di tiap $100 \mathrm{~g}$ (Asante et al., 2014). Satu porsi mi instan substitusi ubi jalar kuning, isolat protein kedelai, dan tepung daun kelor mampu memenuhi 15,8\% kebutuhan AKG hingga sesuai dengan syarat PMT ibu hamil

Tabel 7. Kontribusi Mi Instan Formula Substitusi F2 terhadap AKG dan Standar PMT Ibu Hamil per Takaran Sajian (145 gram)

\begin{tabular}{cccccc}
\hline Formula & Zat Gizi per Saji & AKG Ibu Hamil & $\begin{array}{c}\text { Kontribusi terhadap } \\
\text { AKG Ibu Hamil (\%) }^{(\%)}\end{array}$ & $\begin{array}{c}\text { Standar PMT Ibu } \\
\text { Hamil }^{\mathbf{2}}\end{array}$ & $\begin{array}{c}\text { Kontribusi terhadap } \\
\text { PMT Ibu Hamil (\%) }^{(\%)}\end{array}$ \\
\hline Energi (kkal) & 357,6 & 2550 & $14 \%$ & 450 & $82,2 \%$ \\
Protein (g) & 20 & 76 & $26,3 \%$ & 10 & $200 \%$ \\
Kalsium (g) & 63,5 & 1300 & $5 \%$ & 250 & $25,4 \%$ \\
\hline
\end{tabular}

${ }^{1}$ Kemenkes, (2013a)

${ }^{2}$ Kemenkes, (2016) 
yaitu memenuhi 10-15\% AKG ibu hamil. Tabel 7, memperlihatkan kandungan protein pada mi instan mampu memenuhi kebutuhan protein pada PMT sebanyak 2 kali lipat. Hal ini menjadi nilai lebih mengingat sasaran merupakan ibu hamil dengan kondisi KEK sehingga membutuhkan asupan protein yang cukup tinggi.

Mi instan substitusi ubi jalar kuning, isolat protein kedelai, dan tepung daun kelor formula terbaik menyumbang sebanyak $63,5 \mathrm{mg}$ kalsium per sajian, sehingga mampu berkontribusi sebanyak 5\% terhadap AKG ibu hamil dan sebanyak 25,4\% dalam memenuhi PMT ibu hamil. Hal ini berarti bahwa kalsium yang dikandung pada mi instan substitusi ubi jalar kuning, isolat protein kedelai, dan tepung daun kelor formula terbaik belum mampu memenuhi 10-15\% kebutuhan PMT dalam AKG. Meski dirasa kandungan kalsium pada mi instan substitusi ubi jalar kuning, isolat protein kedelai, dan tepung daun kelor sudah cukup tinggi, namun pada kenyataannya belum mampu menutupi seluruh kebutuhan dalam PMT, mengingat kebutuhan kalsium pada PMT ibu hamil sangat tinggi yaitu sebesar $1300 \mathrm{mg}$ per takaran saji (Kemenkes, 2013).

\section{KESIMPULAN DAN SARAN}

Mi instan dengan penilaian daya terima (warna, aroma, tekstur, dan rasa) dan kandungan gizi (energi, protein dan kalsium) tertinggi adalah F2 yaitu dengan substitusi $25 \mathrm{~g}$ ubi jalar kuning $(6,8 \%), 20 \mathrm{~g}$ isolat protein kedelai $(5,4 \%)$, dan 5 $\mathrm{g}$ tepung daun kelor $(1,4 \%)$. Mi instan substitusi ubi jalar kuning, isolat protein kedelai, dan tepung daun kelor layak dijadikan alternatif PMT ibu hamil karena memiliki kandungan gizi yang lebih banyak daripada mi instan komersial serta telah memenuhi standar produk PMT, yaitu memenuhi $10-15 \%$ kebutuhan energi dan protein ibu hamil.

Jumlah takaran saji yang direkomendasikan peneliti untuk dapat memenuhi kebutuhan AKG sebesar $10-15 \%$ adalah sebanyak $145 \mathrm{~g}$ dalam sehari, sehingga dapat dikonsumsi selama 2 waktu makanan selingan dengan masing-masing sebanyak \pm 70 gram. Selain itu, perlu adanya pengembangan lebih lanjut terhadap formulasi untuk meningkatkan daya terima dan nilai gizi dari mi instan substitusi ubi jalar kuning, isolat protein kedelai, dan tepung daun kelor.

\section{DAFTAR PUSTAKA}

Asante, W.J., Nasare, I.L., Dery, D.T., Boadu, K.O, \& Kentil, K.B. (2014). Nutrient composition of moringa oleifera leaves from tro agro ecological zones in Ghana. African Journal of Plant Science 8(1): 65-71. Diakses dari http:// academicjournals.org.

Astawan, M. (2008). Teknologi pembuatan mie instan. Jakarta: Penerbit Gramedia.

Badan Pusat Statistik. (2016). Statistik Indonesia 2016. Jakarta: BPS. Diakses dari https://www. bps.go.id/.

Badan Standardisasi Nasional. (2000). Standar Nasional Indonesia: Mi instan (SNI 01-35512000). Jakarta: BSN. Diakses dari http://sisni. bsn.go.id/.

Camargo, E.B., Moraes, L.F.S., Souza, C.M., Akutsu, R., Baretto, J.M., Silva, E.M.K., Betran, A.P., \& Torloni, M.R. (2013). Survey of calcium supplementation to prevent preeclampsia: the gap between evidence and practice in Brazil. BMC Pregnancy and Childbirth 13(1): 206. Diakses dari www.biomedcentral.com.

Cameron, E.L. (2014). Pregnancy and olfaction: A Review. Front. Psychol, 5: 67. doi: 10.3389/ fpsyg.2014.00067.

Cindy, B.P.I.R., Suyatno, \& Fatimah, S. (2016). Hubungan konsumsi mi instan dengan status gizi pada balita usia 24-59 bulan di Desa Jamus Kecamatan Mranggen Kabupaten Demak, Indonesia Tahun 2015. Jurnal Kesehatan Masyarakat 4(2):29-37. Diakses dari www. media.neliti.com.

Depkes. (1995). Daftar komposisi zat gizi pangan Indonesia. Jakarta: Kementrian Kesehatan Republik Indonesia.

Ginting, E., Yulifianti, R. \& Jusuf, M. (2014). Ubi jalar sebagai bahan diversifikasi pangan lokal. Jurnal Pangan, 23(2): 194-207. Diakses dari www.jurnalpangan.com.

Hasanah, D.N., Febrianti., \& Minsarnawati. (2012). Kebiasaan makan menjadi salah satu penyebab kekurangan energi kronis (KEK) pada ibu hamil di poli kebidanan RSIA Lestari Cirendeu Tangerang Selatan. Jurnal Kesehatan Reproduksi 3(3): 91-104. Diakses dari www. ejournal.litbang.depkes.go.id. 
Karima, K., \& Achadi, E.L. (2012). Status gizi ibu dan berat badan lahir bayi. Jurnal Kesehatan Masyarakat Nasional 3(7):111-119. Diakses dari www.journal.fkm.ui.ac.id.

Kemenkes. (2013a). Angka kecukupan gizi (AKG). Kementrian Kesehatan Republik Indonesia, Jakarta. Diakses dari http://gizi.depkes.go.id/.

Kemenkes. (2013b). Riset kesehatan dasar (Riskesdas) Tahun 2013. Kementerian Kesehatan Republik Indonesia, Jakarta. Diakses dari www. depkes.go.id.

Kemenkes. (2016). Peraturan Menteri Kesehatan Republik Indonesia Nomor 51 Tahun 2016 Tentang Standar Produk Suplementasi Gizi. Kementrian Kesehatan Republik Indonesia, Jakarta. Diakses dari http://hukor.kemkes. go.id/.

Khasanah, L.U., Kawiji., Utami, R. \& Aji, Y.M. (2015). Pengaruh perlakuan pendahuluan terhadap karakteristik mutu minyak atsiri daun jeruk purut. Jurnal Aplikasi Teknologi Pangan 4(2): 48-55. Diakses dari www.jatp.ift.or.id.

Liandani, W., \& Zubaidah, E. (2015). Formulasi pembuatan mi instan bekatul (kajian penambahan tepung bekatul terhadap karakteristik mi instan). Jurnal Pangan dan Agroindustri 3(1): 174-185. Diakses dari www.jpa.ub.ac.id

Luthfiyah, F. (2012). Potensi gizi daun kelor (moringa oleifera) Nusa Tenggara Barat. Media Bina Ilmiah 6(2): 42-50. Diakses dari http:// www.lpsdimataram.com/.

Mariotti, F., Mahe, S., Benamouzig, R., Luengo, C., Dare, S., Gaudichon, C. \& Tome, D. (1999). Nutritional value of $\left[{ }^{15} \mathrm{~N}\right]$-soy protein isolate assessed from ileal digestibility and postprandial protein utilization in humans. The Journal of Nutrition 129(11): 1992 -1997. Diakses dari https://www.ncbi.nlm.nih.gov.

Nurhidajah, Anwar, S., \& Nurrahman. (2009). Daya terima dan kualitas protein in vitro tempe kedelai hitam yang diolah pada suhu tinggi. Jurnal Gizi Indonesia ISSN 1858-4942. Diakses dari http://eprints.undip.ac.id.

Oktriyani, Juffrie, M., \& Astiti, D. (2014). Pola makan dan pantangan makan tidak berhubungan dengan kekurangan energi kronis pada ibu hamil. Jurnal Gizi dan Dietetik Indonesia 2(3): 159-169. Diakses dari www.ejournal.almaata. ac.id.

Ponomban, S.S., Walalangi, R., \& Harikedua, V.T. (2013). Efektivitas suplementasi bubuk daun kelor (moringa oleifera) terhadap peningkatan kadar hemoglobin pada ibu hamil yang menderita anemia. Jurnal Gizido 5(1): 36-44. Diakses dari www.ejurnal.poltekkesmanado.ac.id.

Rochmawati \& Marlenywati. (2015). Perilaku Konsumsi mi Instan Mahasiswa Fakultas Ilmu Kesehatan Universitas Muhammadiyah dan Jurusan Gizi Poltekkes Kemenkes Pontianak. Jurnal Vokasi Kesehatan 1(6): 188-194. Diakses dari www.ejournal.poltekkes-pontianak.ac.id.

Say, L., Chou, D., Gemmill, A., Tuncalp, O., Moller, A.B., Daniels, J., Gulmezoglu, A.M., Temmerman, M., \& Alkema, L. (2014). Global Causes of Maternal Death: A WHO Sysmatic Analysis. The Lancet Global Health 2(6): 323-333. Diakses dari www.thelancet.com.

Slavin, J. (1991). Nutritional benefits of soy protein and soy fiber. Journal of the American Dietetic Association 91(7): 816-9.

Sundari, D., Almasyhuri., \& Lamid. A. (2015). Pengaruh proses pemasakan terhadap komposisi zat gizi bahan pangan sumber protein. Media Litbangkes 25(4): 235-242. Diakses dari https:// media.neliti.com/.

Syukur, N.A. (2016). Faktor-faktor yang menyebabkan kurang energi kronis (KEK) pada ibu hamil di puskesmas Sidomulyo Kota Samarinda. Mahakam Midwifery Journal 1(1): 38-45. Diakses dari www.ejournalbidan. poltekkes-kaltim.ac.id.

Trisnawati, M., \& Nisa, F.C. (2015). Pengaruh penambahan konsentrat protein daun kelor dan keragenan terhadap kualitas mie kering tersubstitusi mocaf. Jurnal Pangan dan Agroindustri 3(1): 237-247. Diakses dari www. jpa.ub.ac.id/.

Zakaria., Nursalim., \& Tamrin, A. (2016). Pengaruh penambahan tepung daun kelor terhadap daya terima dan kadar protein mi basah. Media Gizi Pangan 21(1): 73-78. Diakses dari http:// mediagizipangan.org. 